\title{
SYNTHESIS, PHYSICOCHEMICAL ANALYSES, AND ANTIBACTERIAL ACTIVITY OF THE FE(III) SALT OF 4-AMINE- $N$-2-THIAZOLYL-BENZENE SULFONAMIDE
}

\author{
MARÍA C. BORDIER ${ }^{1}$, ERCILIA A. NAVARRO ${ }^{1}$, RICARDO CÁMPORA ${ }^{1}$, M. CAROLINA NAVARRO \\ AND M. INÉS GÓMEZ2*
}

\author{
${ }^{I}$ Instituto de Química Analitica, Facultad de Bioquímica, Química y Farmacia, Universidad Nacional de Tucumán, \\ Ayacucho 471, 4000 San Miguel de Tucumán, Tucumán, Argentina. \\ ${ }^{2}$ Instituto de Química Inorgánica, Facultad de Bioquímica, Química y Farmacia, Universidad Nacional de Tucumán, \\ Ayacucho 471, 4000 San Miguel de Tucumán, Tucumán, Argentina.
}

(Received: May 22, 2013 - Accepted: January 23, 2014)

\begin{abstract}
The synthesis and characterization of the Fe(III) complex of sulfathiazole, is presented herein. The compound was prepared by using a conventional precipitation technique, and was characterized by thermogravimetric analysis (TGA), differential thermal (DTA), differential scanning calorimetry (DSC) under oxygen atmosphere, chemical analysis, infrared spectroscopy, powder ray-X diffraction (PXRD), and scanning electron microscopy (SEM). The antibacterial activity of the complex was screened against S. aureus, showing an appreciable activity, compared with the free ligand.
\end{abstract}

Keywords: Sulfonamide - iron(III) complex - sulfathiazole ligand.

\section{INTRODUCTION}

Sulfathiazole (ST) or $p$-amino-benzenesulfonamide is a synthetic substance derived from sulfanilamide by replacing one amidic hydrogen by a thiazole group ${ }^{1,2}$. Sulfathiazole was the first effective chemotherapeutic agent systematically employed for the prevention and cure of bacterial infections in humans ${ }^{3}$. In addition, the sulfa drugs have been used in food-producing animals, to promote their growth, and for therapeutic and prophylactic purposes ${ }^{4,5}$. The sulfanilamides carry out their antibacterial action by the competitive inhibition of the enzyme dihydropterase synthetase towards the $p$-aminobenzoate substrate ${ }^{6}$.

ST is clinically one of the most used drugs. Casanova et al. have reported its use in the inhibition of carbonic anhydrase and superoxide dismutase activity $^{7,8}$.

Besides, ST and their metal complexes have many applications, such as diuretic, antiglaucoma or antiepileptic drugs, among others,, 10 and in many cases, the activity of the complexes is much better than the free ligand ${ }^{11,12}$.

In the last years, we have synthezised and studied the structural and physicochemical properties of metallic complexes which have interesting applications, such as their use as precursors to obtain oxides by thermal decomposition $^{13-16}$.

In this work, we report the preparation, physicochemical analysis and antibacterial activity of iron(III) sulfathiazole.

The interest for studying the behavior of Fe(III) against sulfathiazole is due to the fact that most of the researches relate to divalent ions. Moreover, the synthesized sulfa could possibly have topical therapeutic applications s-12,17,18. $^{\text {. }}$

\section{EXPERIMENTAL}

\subsection{Synthesis of the iron complex}

The preparation of this compound was carried out at room temperature, using an ordinary precipitation method ${ }^{19}$. A $0.1 \mathrm{M}$ solution of iron(III) chloride was added dropwise and with stirring to a $0.3 \mathrm{M}$ solution of sodium sulfathiazole. An abundant yellow precipitate was obtained, isolated by filtration with Whatman $\mathrm{N}^{\circ} 42$ filter paper, apropriate for fine crystals, washed with distilled water until absence of iron (III) in the filtrate, and dried in an oven at $100{ }^{\circ} \mathrm{C}$. The weight of the solid obtained corresponded to $97 \%$ of the theoretical yield.

Aging of the precipitate: the compound, prepared as described above, was left in contact with bidistilled water, at room temperature for 210 days. At certain time intervals, samples were taken to analyze $\mathrm{Fe}(\mathrm{III})^{16,19}$.

\subsection{Chemical analysis and physicochemical properties}

$\mathrm{Fe}(\mathrm{III})$ was determined using two different techniques whose results were compared: a) A dry chemical technique for measuring reflectance in a Vitros Analyzer 250 equipment, and b) the classic technique of $o$-phenanthroline ${ }^{20}$.

To determine sulfathiazole, $0.1 \mathrm{~g}$ the precipitate was dissolved in $1 \mathrm{~mL}$ of concentrated $\mathrm{HCl}$ and then diluted with $10 \mathrm{~mL}$ of distilled water. ST was confirmed through a process of diazotation ${ }^{21,22}$. To avoid color interference it was necessary to mask Fe(III) cation with $\mathrm{H}_{3} \mathrm{PO}_{4}$. Density, solubility, specific surface area and Kps of the compound were calculated, and the used methodology was reported in a previous work ${ }^{16,23}$.

\subsection{Characterization}

The thermal decomposition process of the complex was studied by thermogravimetric, differential thermal analysis (TGA/DTA) and differential scanning calorimetry (DSC). TGA and DTA were performed on a Termogravimetric and Differential Thermal Analyzer Shimadzu TGA/DTA-50 at $5{ }^{\circ} \mathrm{C} / \mathrm{min}$ in a gas flow of $20 \mathrm{~mL} / \mathrm{min} . \mathrm{Al}_{2} \mathrm{O}_{3}$ was used as DTA standard. The DSC was performed in a Perkin Elmer Thermal Analysis with a heating rate of $10{ }^{\circ} \mathrm{C} / \mathrm{min}$.

IR spectra were recorded with a FTIR Perkin Elmer 1600 in the transmission mode from $4000-400 \mathrm{~cm}^{-1}$, using $\mathrm{KBr}$ pellets.

The size and morfology of the particles were determinated by scanning electron microscopy (SEM) with a JEOL JSM 35 CF.

PXRD pattern was performed in a Rigaku Miniflex Diffractometer with $\mathrm{CuKa}$ radiation $(\lambda=1.5418 \AA)$ between $20-90^{\circ}$ in $2 \theta$, steps of $0.02^{\circ}$ and counting time of $4 \mathrm{~s}$.

\subsection{Bacteriostatic assays}

In order to evaluate the bacteriostatic activity, the minimun inhibitory concentration (MIC), of iron(III) complex and sodium sulfathiazole salt was determined against S. aureus ATCC 25923 (American Type Culture Collection) and $S$. aureus obtained from a patient of the private microbiology laboratory. It was used the microdilution method following the specifications of the National Committee for Clinical Laboratory Standard (NCCLS) ${ }^{24}$. Briefly: 1 $\mathrm{mL}$ of bacterial suspension in the last phase of growth was inoculated in $1 \mathrm{~mL}$ of Mueller Hinton Broth containing the compounds in the final concentration ranging from 128 to $0.25 \mu \mathrm{g} / \mathrm{mL}$. The final inoculum was approximately $1 \times 10^{5}$ viable bacteria/mL and final volume $2 \mathrm{~mL}$. Inoculated tubes were incubated at $35^{\circ} \mathrm{C}$ for $24 \mathrm{~h}$. The readings were made visually by turbidity. The MIC was defined as the lowest concentration of antimicrobial agent showing complete inhibition of growth.

\section{RESULTS AND DISCUSSION}

3.1. Composition of precipitate. Physicochemical properties

From the chemical analysis it is determined that the precipitate contains $91.00 \%$ of sulfathiazole and $8.80 \%$ of Fe(III). The results of the solubility for the original and aged precipate were consistent in the used methods. The results of density, solubility, specific surface area and Kps of the aged and recent compound are shown in Table 1, and the values of pKps and ln C for different aging times in the Table 2, and Fig. 1. 
Table 1: Physical and chemical properties of iron(III) sulfathiazole.

\begin{tabular}{|c|c|c|c|}
\hline & Properties & Recent & Aging \\
\hline & Density (g/mL ) & 1.478 & 1.516 \\
\hline \multirow{2}{*}{ 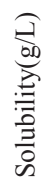 } & $o$-phenanthroline & $1.04 \times 10^{-3}$ & $1.31 \times 10^{-8}$ \\
\hline & Dry chemical & $1.07 \times 10^{-3}$ & $1.38 \times 10^{-8}$ \\
\hline & $\begin{array}{l}\text { surface area } \\
\left(\mathrm{m}^{2} \mathrm{~g}^{-1}\right)\end{array}$ & 0.2744 & 0.2132 \\
\hline & $\mathrm{Kps}\left(\mathrm{mol}^{4} / \mathrm{L}^{4}\right)$ & $3.45 \times 10^{-18}$ & $9.55 \times 10^{-24}$ \\
\hline
\end{tabular}

Table 2: Values of pKps and $\ln \mathrm{C}$ for different aging times.

\begin{tabular}{|c|c|c|}
\hline Time (days) & pKps & $\ln \mathrm{C}$ \\
\hline 3 & 17.49 & -13.88 \\
\hline 15 & 17.89 & -14.19 \\
\hline 30 & 18.66 & -14.78 \\
\hline 40 & 18.92 & -14.99 \\
\hline 70 & 19.87 & -15.71 \\
\hline 120 & 21.70 & -17.12 \\
\hline 150 & 22.79 & -17.96 \\
\hline 180 & 23.00 & -18.11 \\
\hline 210 & 23.04 & -18.15 \\
\hline
\end{tabular}

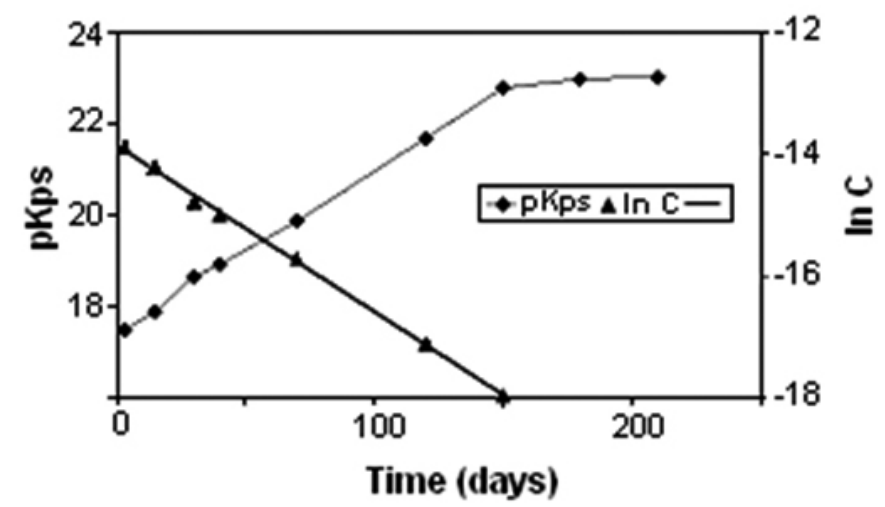

Fig. 1: pKps as a function of aging time.

3.2. Structure of $\mathrm{Fe}(\mathrm{ST})_{3}$

In the structure of the complex, the central atom is Fe(III) which forms $\mathrm{d}^{2} \mathrm{sp}^{3}$ hybrid orbitals, allowing us to assign a coordination number six ${ }^{25}$. These coordination sites can be occupied by three bidentate ligands of the sulfathiazole anion. The binding of the ligand to the central atom occurs through the oxygen of the sulfonyl group and thiazolic nitrogen, forming six-membered rings of the type chelate. The most likely spatial disposition would be octahedral.

From PXRD data using the Le Bail Method and the Fullprof Program is determined that the complex crystallizes in the monoclinic crystal system, $P 2 / \mathrm{m}$ space group ${ }^{26,27}$. The results of refinement are shown Fig. 2, and Table 3 .

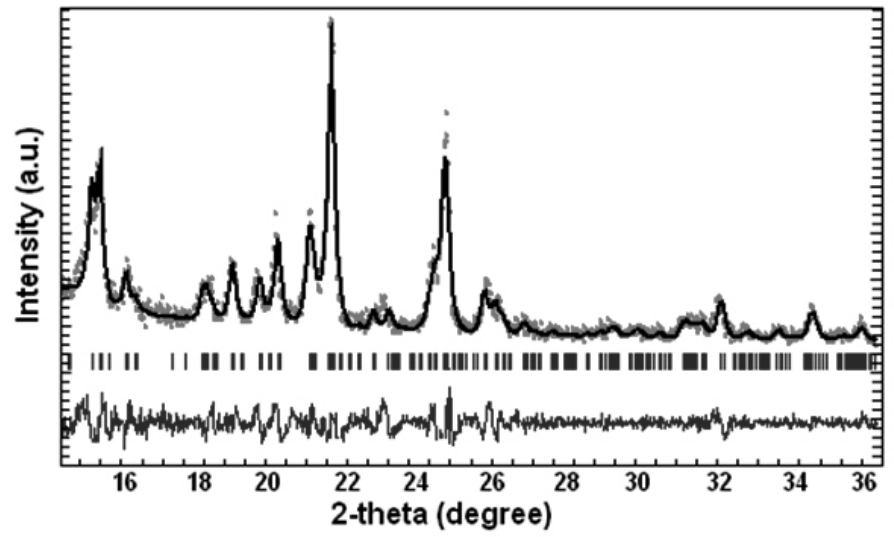

Fig. 2: PXRD pattern of iron(III) sulfathiazole refined in the space group $P 2 / \mathrm{m}$

Table 3: Crystal data and structure refinement for $\mathrm{Fe}(\mathrm{ST})_{3}$

\begin{tabular}{|c|c|}
\hline Empirical formula & $\mathrm{C}_{27} \mathrm{H}_{24} \mathrm{FeN}_{9} \mathrm{O}_{6} \mathrm{~S}_{6}$ \\
\hline Formula weight & 818.789 \\
\hline Wavelength, $\AA$ & 1.5418 \\
\hline Crystal system & Monoclinic \\
\hline Space group & $P 2 / \mathrm{m}$ \\
\hline Unit cell dimensions, $\AA$ & $\mathrm{a}=18.70219(5)$ \\
\hline & $\mathrm{b}=7.48602(5)$ \\
\hline Angle, ${ }^{\circ}$ & $\mathrm{c}=9.73557(6)$ \\
\hline & $\mathrm{a}=\gamma=90$ \\
\hline${\text { Volume, } \AA^{3}}^{3}$ & $\beta=95.27918(9)$ \\
\hline $\mathrm{Z}$ & $1357.25(6)$ \\
\hline Refinement method & 2 \\
\hline Program & Le Bail \\
\hline Parameters discrepancy & $\mathrm{R}_{\text {wp }}=25.8 ; \chi^{2}=1.78$ \\
\hline
\end{tabular}

3.3. Thermogravimetric analysis (TGA), differential thermal analysis (DTA) and differential scanning calorimetry (DSC)

TGA curve (Fig. 3) shows that the synthesized iron(III) sulfathiazole is anhydrous because the weight remains constant up to $250^{\circ} \mathrm{C}$. The decomposition is carried out in three stages with a total weight loss of $98.50 \%$. At about 440 ${ }^{\circ} \mathrm{C}$ starts the most significant weight loss and ends at about $600{ }^{\circ} \mathrm{C}$. The final product is iron(III) oxide, which was identified by IR spectroscopy.

DTA curve (Fig.3) shows two endothermic peaks located at $165^{\circ} \mathrm{C}$ and $198{ }^{\circ} \mathrm{C}$. The first peak corresponds to a crystallographic phase change, and the second to the sample melting. This was confirmed by studies of DSC (Fig. 4), which indicated that the first transition begins at $162.38{ }^{\circ} \mathrm{C}$ and ends at $170.46{ }^{\circ} \mathrm{C}$ and the second onsets at $198.31^{\circ} \mathrm{C}$ and ends at $202.19^{\circ} \mathrm{C}$. The crystallographic phase change involves a $\Delta \mathrm{H}=26.609 \mathrm{~J} / \mathrm{g}$ and the sample fusion involves a $\Delta \mathrm{H}=111.520 \mathrm{~J} / \mathrm{g}$. These findings agree with previous studies on polymorphism of sulfonamides ${ }^{28,29}$. After that, in the DTA there are three exothermic peaks at $247.5^{\circ} \mathrm{C}, 455.2{ }^{\circ} \mathrm{C}$ and $477.5^{\circ} \mathrm{C}$ that correspond to the decomposition of iron(III) sulfathiazole, as shown in the TGA curve. 


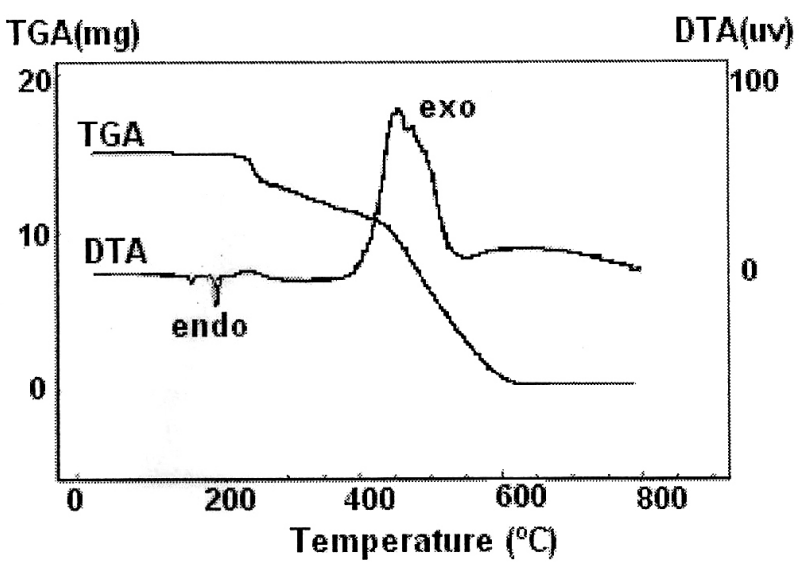

Fig. 3: TGA and DTA data of iron(III) sulfathiazole.

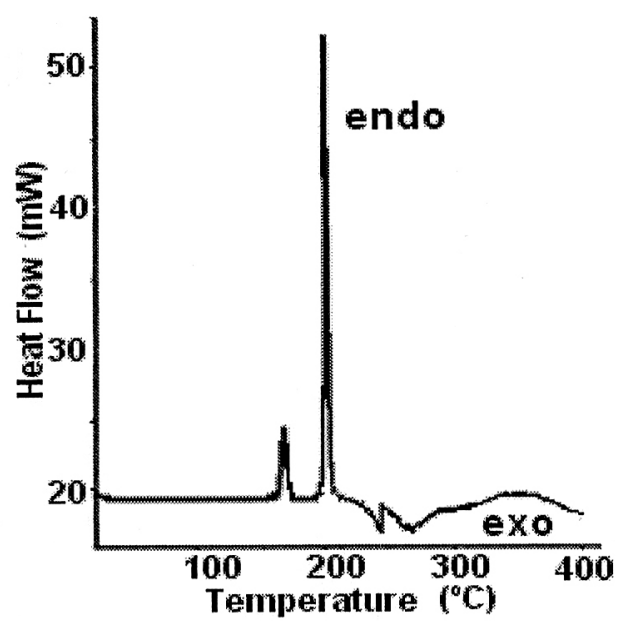

Fig. 4: DSC data of iron(III) sulfathiazole.

\subsection{IR spectra}

The IR spectrum of the compound (Fig. 5 a) displays the typical bands (stretching and deformations) of the thiazole, sulfonyl, amine and benzene groups $^{30-32}$.

The stretching vibrations in free sulfathiazole, attributed to the $\mathrm{SO}_{2}$ group, appear at 1320,1150 and $560 \mathrm{~cm}^{-1}$. However, when the $\mathrm{SO}_{2}$ group is bound to metal through the $\mathrm{O}$ atom, the anti-symmetric and symmetric stretchings become apparent at $1325 \mathrm{~cm}^{-1}$ and $1140 \mathrm{~cm}^{-1}$, respectively ${ }^{31}$.

As a result of the deprotonation of the sulfathiazole ligand and its coordination through the $\mathrm{N}$ thiazole atom, significant changes in the bands assigned to the thiazole ring at $1540 \mathrm{~cm}^{-1}$ in ST, and at $1531.6 \mathrm{~cm}^{-1}$ in $\mathrm{Fe}(\mathrm{ST})_{3}$, and to the S-N stretching at $920 \mathrm{~cm}^{-1}$ in ST, and at $945 \mathrm{~cm}^{-1}$ in the complex, are observed.

In order to isolate the intermediate products and obtain their infrared spectra, the pyrolysis of the compound was performed in furnace. In Figures $5 \mathrm{~b}$ and $5 \mathrm{c}$, the spectra of the wastes obtained to $350{ }^{\circ} \mathrm{C}$ and $600{ }^{\circ} \mathrm{C}$, respectively, are shown. In the IR spectrum it is confirmed the elimination of thiazole ring at $350{ }^{\circ} \mathrm{C}$ by the disappearance of the band located at $1531.6 \mathrm{~cm}^{-1}$. Furthermore, the presence of the typical bands of the $-\mathrm{SO}_{2}$ group suggests that iron benzenesulfonate was formed as an intermediate product (Fig.5 b). We noted that the final residue at $600{ }^{\circ} \mathrm{C}$ corresponds to reddish brown $\mathrm{Fe}_{2} \mathrm{O}_{3}$, which was checked against an infrared spectrum of a true sample (Fig. 5 c). From the results of IR spectroscopy, the chemical reactions during thermal decomposition could be represented as:

$\mathrm{Fe}\left(\mathrm{C}_{9} \mathrm{H}_{8} \mathrm{~N}_{3} \mathrm{O}_{2} \mathrm{~S}_{2}\right)_{3}(\mathrm{~s}) \quad \phi \Rightarrow 3 \mathrm{C}_{3} \mathrm{H}_{2} \mathrm{NS}_{(\mathrm{g})}+\left(\mathrm{C}_{6} \mathrm{H}_{6} \mathrm{~N}_{2} \mathrm{O}_{2} \mathrm{~S}\right)_{3} \mathrm{Fe}_{(\mathrm{s})} \quad\left(350^{\circ} \mathrm{C}\right)$

$\left(\mathrm{C}_{6} \mathrm{H}_{6} \mathrm{~N}_{2} \mathrm{O}_{2} \mathrm{~S}\right)_{3} \mathrm{Fe}_{(\mathrm{s})} \quad \phi \Rightarrow 1 / 2 \mathrm{Fe}_{2} \mathrm{O}_{3(\mathrm{~s})} \quad+$ other volatile products $\left(>600^{\circ} \mathrm{C}\right)$

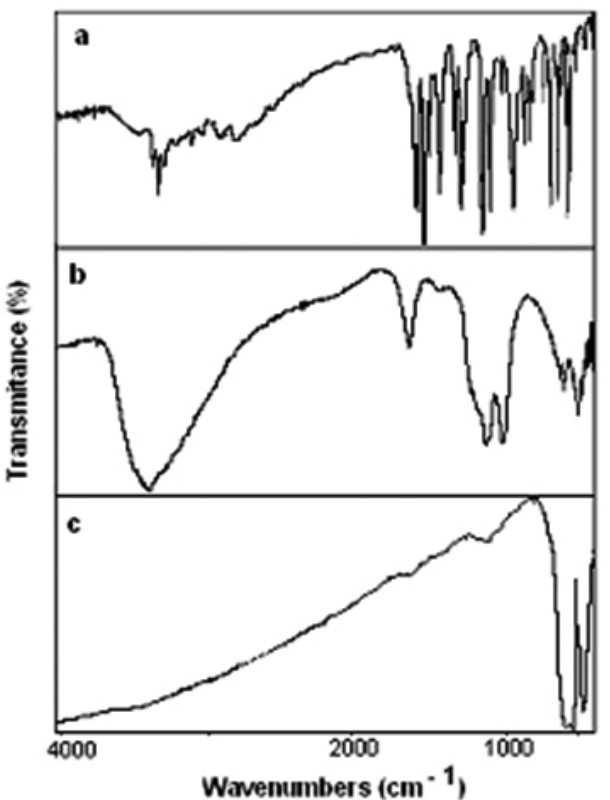

Fig. 5: a) IR spectrum of original compound. b) IR spectrum of residue at $350{ }^{\circ} \mathrm{C}$ and c) IR spectrum of residue at $600^{\circ} \mathrm{C}$.

3.5. Scanning Electron Microscopy (SEM)

Fig. $6 \mathrm{a}$ and $\mathrm{b}$ show the SEM photographs of recent and aged $\mathrm{Fe}(\mathrm{ST})_{3}$ precipitate, respectively. It is noted that the aging of the compound in the presence of the mother liquor leads to the formation of crystals about a hundred times larger than the original.

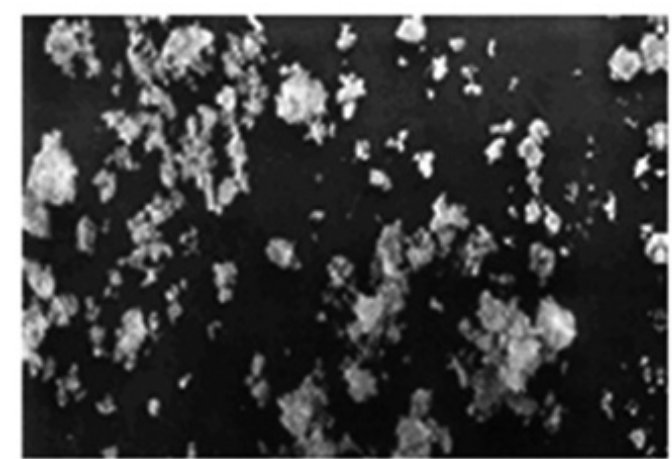

a)

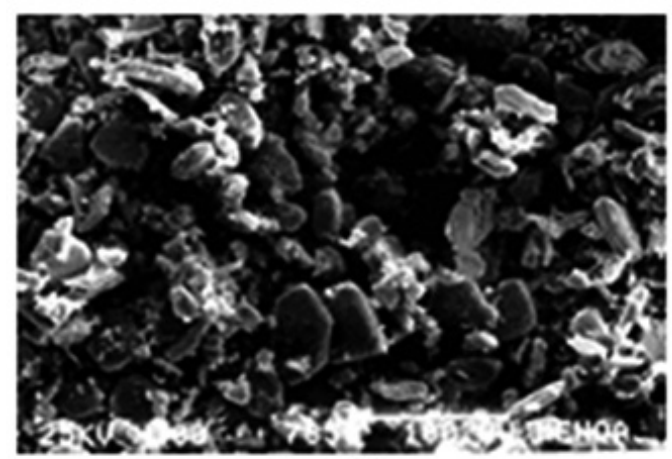

b)

Fig. 6: SEM of iron (III) sulfathiazole: a) recent, b) after aging. 


\subsection{Antimicrobial Activity}

The bacteriostatic activity of the complex and of the sodium sulfathiazole salt was evaluated against $S$. aureus using the microdilution method. Table 4 shows minimum inhibitory concentration (MIC) of the drugs for $S$. aureus ATCC 25923 and S. aureus obtained from a patient of the private microbiology laboratory.

MIC values of $\mathrm{Fe}(\mathrm{ST})_{3}$ were lower than the corresponding free ligand in the same conditions. The activity of complex was better against the $S$. aureus from the laboratory private patient than against the ATCC 25923 one. Bellú et $a l$. have obtained similar results in the determination of the antibacterial activity of $\mathrm{Hg}(\mathrm{II})$ sulfathiazole against $E$. Coli ${ }^{12}$.

Recently, it has been reported the antibacterial activity of benzohydrazone derivatives against Escherichia coli, Staphylococcus aureus, and Klebsiella pneumonia and the results indicate that the compounds show moderate activities against the growth of the tested strains ${ }^{33}$.

Table 4: Minimum inhibitory concentration (MIC, $\mu \mathrm{g} / \mathrm{mL}$ ) of the drugs for $S$. aureus ATCC 25923 and S. aureus obtained from a patient of the private microbiology laboratory.

\begin{tabular}{|c|c|c|}
\hline Sulfadrug & $\begin{array}{c}\mathrm{MIC}, \mu \mathrm{g} / \mathrm{mL} \\
\text { S.aureus ATCC } 25923\end{array}$ & $\begin{array}{c}\mathrm{MIC}, \mu \mathrm{g} / \mathrm{mL} \\
\text { S.aureus from patient }\end{array}$ \\
\hline $\mathrm{Fe}(\mathrm{ST})_{3}$ & 47 & 15 \\
\hline $\begin{array}{c}\text { Sulfathiazole } \\
\text { (sodium salt) }\end{array}$ & $>95$ & $>95$ \\
\hline
\end{tabular}

\section{CONCLUSIONS}

The preparation of iron(III) sulfathiazole was carried out at room temperature using a ordinary precipitation method.

Through chemical and spectroscopic analysis we found that sulfathiazole forms an anhydrous complex with $\mathrm{Fe}(\mathrm{III})$ in a 3:1 molar ratio, which is slightly soluble in water, according to the Kps values.

The aging of the synthesized product leads to significant growth of crystals. This explains why the solubility and specific surface area decrease with time.

The MIC values indicate that $\mathrm{Fe}(\mathrm{III})$ sulfathiazole presents better antibacterial activity against $S$. aureus than the corresponding ligand.

Acknowledgments. The authors thank "Consejo de Investigaciones de la Universidad Nacional de Tucumán” (CIUNT), for financial support.

\section{REFERENCES}

1. M. Litter. Las sulfonamidas y otros quimioterápicos: las diaminopirimidinas. Compendio de Farmacología, El ateneo, Buenos Aires, Argentina, 749 (1992).

2. A. Velasco, P. Lorenzo, J. Serrano. Farmacología Velásquez, $16^{\text {th }}$ Ed., Interamericana McGraw-Hill, Madrid, España, 894, (1993).

3. F. Blasco, L. Perelló, J. Latorre, J. Borrás, S. García Granda, J. Inorg. Biochem. 61, 143, (1996).

4. D. E. Dixon Holland, S. E. Katz, J. Assoc. Off. Anal. Chem. 74, 784, (1991).
5. Y. Wen, M. Zhang, Q. Zhao, Y. Feng, J. Agric. Food Chem. 53, 8468, (2005)

6. A. García-Raso, J. J. Fiol, S. Rigo, A. López-López, E. Molins, E. Espinosa, E. Borrás, G. Alzuet, J. Borrás, A. Castiñeiras, Polyhedron 19, 991, (2000).

7. D. Alzuet, J. Inorg. Biochem. 75, 189, (1999).

8. J. Casanova, G. Alzuet, S. Ferrer, J. Latorre, J. Ramírez, J. Borrás, Inorg. Chim. Acta 304, 170, (2000).

9. A. Scozzafava, L. Menabuoni, F. Mincione, F. Briganti, G. Mincinone, C. Supuran, J. Med. Chem. 42, 2641, (1999).

10. C. Supuran, A. Scozzafava, J. Enzime Inhib. 13, 37, (1997).

11. G. M. Golzar Hossain, J. Saudi Chem. Soc. (2011) doi 10.1016/j. jscs.2011.04.002.

12. S. Bellú, E. Hure, M. Trapé, M. Rizzotto, E. Sutich, M. Sigrist, V. Moreno, Quimica Nova 26, 188, (2003).

13. D. Gil, R. Carbonio, M. I. Gómez, J. Chil. Chem. Soc. 55, 189, (2010)

14. D. Gil, M. Avila, E. Reguera, S. Pagola, M. I. Gómez, R. Carbonio, Polyhedron 33, 450 (2012). Doi: 10.1016/j.poly.2011.12.006.

15. D. Gil, J. Guimpel, A. Paesano Jr., R. Carbonio, M.I. Gómez, J. Mol. Struct. 1015, 112, (2012)

16. M. Bordier, J. de Morán, E. Navarro y M. I. Gómez, Inf. Tecnol. 18, 77, (2007).

17. J. R. Anacona, J. Diaz, J. Chil. Chem. Soc. 53, 1702, (2008).

18. S. Bellú, E. Hure, M. Trapé, C. Trossero, G. Molina, C. Drogo, P.A.M. Williams, A. Atria, J.C. Muñoz Acevedo, S. Zacchino, M. Sortino, D. Campagnoli, M. Rizzotto, Polyhedron 24, 501, (2005).

19. V. Acevedo, M. Rodríguez, J. Giménez, Inf. Tecnol. 12, 81, (2001).

20. D. Skoog, D. West, F. Holler, S. Crouch. Química Analítica, $7^{\text {th }}$ Ed., McGraw -Hill, Guadalajara, México, (2003).

21. Argentina National Formulary, $7^{\text {th }}$ Ed., Codex, Buenos Aires-Argentina, (2000).

22. US Pharmacopeia, $29^{\text {th }}$ Ed., The United Status Pharmacopeial Convention, Rockville, MD, (2006)

23. C. H. Giles, A. S. Trivedi, Chem. and Industry 40, 1426, (1969).

24. National Committee for Clinical Laboratory Standard Performance Standards Antimicrobial Susceptibility Testing, NCCLS Document M 100- S10, NCCLS 771 East Lancaster Avenue, Villanova, Pennsylvania 19085, USA, (2000)

25. J. Huheey, E. Keiter, R. Keiter. Química Inorgánica. Principios de estructura y reactividad, $4^{\text {th }}$ Ed., Ed. Alfaomega. D.F.México, (2005).

26. A. Le Bail, H. Duroy, J. L. Fourquet, Mat. Res. Bull. 23, 447 (1985).

27. J. Rodriguez-Carbajal, Physica B 192, 55 (1993).

28. D. Wirth, G. Stephenson, Org. Process Res. Dev. 1, 55, (1997).

29. G. Z. Zhang, C. Gu, M.T. Zell, R.T. Burkhardt, E.J. Munson, D.J.W. Grant, J Pharm. Sci. 91, 1089, (2002).

30. K. Nakamoto. Infrared and Raman Spectra of Inorganic and Coordination Compounds, $4^{\text {th }}$ Ed., A Wiley. Interscience Publication, (1986).

31. B. Smith. Infrared spectral interpretation, $1^{\text {st }}$ Ed., CRC Press, New York, United States of America, (1998).

32. R. Silverstein, F.Webster. Spectrometric identification of organic compounds, $6^{\text {th }}$ Ed., John Wiley \& Sons, Inc. New York, United States of America, (1996)

33. Z. Wang, F. Zhi, R. Wang, L. Xue, Y. Zhang, Q. Wang, Y-Lin Yang, J. Chil. Chem. Soc. 58, 2, (2013). 